\title{
Extended Release Dosage Form for Suspension
}

National Cancer Institute

\section{Source}

National Cancer Institute. Extended Release Dosage Form for Suspension. NCI

Thesaurus. Code C60929.

A substance that forms a suspension upon reconstitution and designed to release active and/or inert ing redient(s) at a controlled, prolonged rate so as to reduce dosing frequency. 